\section{Letters to the Media of October 20, 2017}

|Piotr Szczęsny

\section{Translator's Note}

Along with the leaflet, Piotr Szczęsny wrote two short letters, referred to as "Letters to the Media." They were handed over by Szczęsny's family to the major media outlets and published on october 20, 2017.

The translation is based on the original publication in Oko.Press, october 20, 2017, WWw. oko. press/piotr-s-szary-czlowiek-zyje-czescpamieci.

Bogna M. Konior

\section{First Letter}

I have done so little for my Motherland.

I was born in 1963, which puts me in a good position to remember $\mathrm{PRL},{ }^{1}$ to remember Solidarność, the regaining of independence and the forming of our democracy. Because of that, I can better evaluate the current events.

I was still in high school when Solidarność was ignited. And in this high school, alongside my classmates, we started an Independent Students' Union, for there was no way to join Solidarność for underage students.

1 Polish People's Republic, the official name of Poland between 1952 and 1989; translator's note.
On December 13 [1981] I was already a university student, I had been up until noon handing out my first leaflets. Under martial law [1981-1983] I did what millions of others did in Poland - handed out leaflets, went to demonstrations, listened to Radio Free Europe, burned candles in my window.

On June 4, 1989, I participated with joy in the first partially free elections and in all the subsequent ones.

My contribution to regaining independence has been microscopic, I am ashamed that I have thus far done so little for my Motherland. And I know that I need to change it.

\section{Second Letter}

I am ashamed to explain that Poland is not the same as the Polish government.

I am ashamed to have a President, who is the president of his party and its supporters only, and who breaks the constitution (the vetoing of two unconstitutional bills, only in order to propose two other, still unconstitutional bills, is no redemption).

I am ashamed to have a Prime minister who follows party orders.

I am ashamed to explain to my western friends that Poland is not the same as the Polish government. 
I am ashamed to have to use again the term "nomenclature" and the phrase "the party and the government" as in the times of PRL.

I am ashamed to witness the defamation of people who earned nothing but respect for what they have done for free Poland.

Translated from the Polish by

Bogna M. Konior 